\title{
Gender and Financial Constraints: An Empirical Investigation in Italy
}

\author{
Francesco Campanella ${ }^{1} \&$ Luana Serino $^{1}$ \\ ${ }^{1}$ Department of Economics, University of Campania L. Vanvitelli, Capua, Italy \\ Correspondence: Luana Serino, Department of Economics, University of Campania L. Vanvitelli, Corso Gran \\ Priorato di Malta,1, Capua,81043, Caserta, Italy.
}

Received: March 22, 2019

Accepted: April 9, 2019

Online Published: April 14, 2019

doi:10.5430/ijfr.v10n2p109

URL: https://doi.org/10.5430/ijfr.v10n2p109

\begin{abstract}
Firms can be credit constrained either because they decide not to apply for such a loan due to expected rejection or because the application has been rejected by the bank. Using a sample of 428 Italian small and medium enterprises, we investigate the relationship between gender and credit constraints. Controlling for other variables, findings reveal that lenders discriminate against women on the basis solely of gender in terms of access to capital. As a consequence, women-run firms obtain less bank financing, although they are not afraid to ask for credit.
\end{abstract}

Keywords: businesses, credit access, financial constraints, gender

\section{Introduction}

Access to capital is a critical factor in stimulating growth and development of small businesses. A large body of the existing literature has documented that banks are the main external capital provider for SMEs sector (Cole \& Wolken, 1995; Ono \& Uesugi, 2009; Vera \& Onji, 2010). This article examines the extent to which personal owner' characteristics influence the likelihood of firm to rely on debt capital. Our study focused on Italian Small and Medium enterprises because they are an important source of economic growth and job creation. According to Cerved report on SMEs of 2017, the number of SMEs is steadily increasing, and they account for about $90 \%$ of businesses. In addition, profitability levels are close to pre-crisis ones, with a recovery that has very solid financial and income bases. $\mathrm{n}$ this context, in order to favor the gender diversity in top management, the European Union Commission (EUC) stated that $40 \%$ of all board seats must be filled with the gender minority by end 2020 (Reding, 2013). For all small businesses, regardless of the owner's gender, bank lending is the most important source of external financial resources (Berger \& Udell, 2002). However, several studies stated that for women-run businesses securing bank credit is difficult (Coleman, 2000). On one side, it is often argued that women represent one group of persons frequently discriminated in credit markets. On the other side, a body of literature stated that there is no a lender discrimination against women, but the limited access to credit by women can be explained by a lack of loan demand by female entrepreneurs. The increasing contribution of women-owned businesses to the growth of Italian economy makes it important to address the difficulties faced by women-owned businesses.

This study aims to investigate the issue of discrimination against women in Italian credit markets. This analysis is conducted by, first, exploring the distribution of applicants and non-applicants for bank credit among men and women entrepreneurs and, second, measuring the degree of success they have in obtaining the credit requested.

Hence, this empirical research is aimed to test two questions related to access to bank lending by women-owned businesses. First, are women-owned businesses less likely to apply for bank loans than businesses owned by men? Second, when they apply, are women-owned businesses less likely to be approved?

We begin with a review of literature and next we describe the survey data used to test our hypotheses. Subsequently, we present the main results of our paper. In the last section, we present the research conclusions and managerial implications.

\section{Literature Review}

\subsection{Definition of SMEs}

Prior research has attempted to define what constitutes a SME, but the definition varies from country to country among researchers, and there is not a universal accepted definition. The definitions are based on different criteria such as number of employees, financial position, the value of sales or assets (Beck et al., 2005; Zindiye et al., 2008). Even the 
criteria and the measures vary from country to country and from institution to institution. For the purpose of this study, the definition of SMEs is based on the number of employees of a firm. Specifically, in accordance with the EU definitions (European Commission, 2003), SMEs include all the businesses which have less than 250 employees. Then, the number of the employee is the cut off used for SMEs definition. The study was conducted on registered and independent Small and Medium Enterprises in Italy.

\subsection{SMEs' Access to Bank Credit}

Bank credit is a crucial element for the development of economic system. However, the literature stated that small firms face major difficulties in accessing to bank credit. Empirical evidence suggested that lack of access to financing is a major constraint to financial performance (Baliamoune-Lutz, Lutz, 2017), in particular in Italy that is a banking-based country (Tardivo, Miglietta, Schiesari, Battisti, 2012). The prevailing view argued that firm size is a significant determinant of credit constraint status because smaller firms are more opaque than larger ones (Coleman, 2004; Berger \& Udell, 2006; Degryse \& Van Cayseele, 2000). It is accepted that lenders discriminate on the basis of firm size, preferring to lend to larger and more established (Coleman, 2000) as real value of smaller firms more resides in non-codified information that cannot be transmitted electronically (Alessandrini, Presbitero \& Zazzaro, 2009), and that tends to be difficult to quantify, verify, and communicate through the standardized transmission channels of a banking organization (Berger \& Udell, 2002). This assumption makes SMEs more risky borrower from the lending point of view that tends to prefer larger firms.

Therefore, the different sources of external finance for firm' development are classified into three categories: formal debt finance, which includes bank and non-banking financial institutions, trade finance, comprising credit from suppliers and customers, and finally informal sources of credit. The last category of credit is considered as the last resort for credit-constrained borrowers (Bell, Srintvasan \& Udry, 1997; Ghosh, Mookherjee \& Ray, 2000).

However, small and medium enterprises finance a larger share of investment with informal sources of finance such as moneylenders or family, friends and relatives (Azam et al., 2001; Beck, Demirgüç-Kunt \& Levine, 2005; Hanedar, Broccardo \& Bazzana, 2014). Several studies (Fatoki \& Odeyemi, 2010; Mukiri, 2008; Kira, 2013) found how hard it is for SMEs to access bank loan, by indicating that a large percentage of SMEs which had applied for loan from commercial bank were rejected. In other word, SMEs have lower likelihood to access bank loan than larger firms.

\subsection{Women-Run Firms' Credit Access}

The personal characteristics of the owner also make a difference both to the firm's propensity to ask for bank loans and likelihood of accessing external finance (Irwin \& Scott, 2010; Cassar, 2004; Scuotto et al., 2019). Because SMEs access to finance are dependent on the ability of a single individual (that is the owner/manager) to access to bank loans, in this paper we analyzed the relationship between the owner characteristics and the likelihood of the firm to be funded.

The characteristics analyzed in this paper are: gender, age, education, experience.

About the gender, female and male entrepreneurs generally differ in the way they finance their businesses (Carter, 2000). In particular, women run firms face major difficulties in accessing to bank credit than male counterparts (Le \& Stefańczyk, 2018).Generally, the reduction in credit availability is due to demand and supply-side factors. Women's lesser use to external financial resources was explained by researchers using three different approaches. Firstly, female firms have difficulty accessing bank finance, but this pattern seems to be mainly explained by the structural characteristics of women owned firms rather than by a problem of gender-discrimination. These differences in structural terms make female firms undesirable from a banking point of view, therefore not very "bankable" (Stefani \& Vacca, 2014). Riding and Swift (1990), in a survey conducted among Canadian businesses found that women principals receive credit under financing conditions that are less favorable than those applied for male business owners because of structural features of female firms. Female firms are on average younger and smaller than male businesses, they tend to be concentrated in less capital-intensive sectors, they have lower rates of sale growth, and more likely to be organized as partnerships or proprietorships rather than corporations. For these characteristics, women-owned firms may be considered riskier by banks (Angori, Aristei \& Gallo, 2017; Coleman \& Carsky, 1996; Coleman \& Carsky, 1990; Coleman \& Robb, 2009; Fabowale, Mascia, 2018; Orser \& Riding, 1995). Rather than discriminating against women, Coleman (2000:46) concluded that banks "discriminate on the basis of firm size, preferring to lend to larger and, one would assume, more established firms. This preference may put women at a disadvantage given that they are half the size of men-owned firms on average."(p. 49).

The second approach, in contrast with the previous one, argues that difficulties in accessing bank credit can be the result of supply side discrimination by bankers against women owners. Indeed, some works suggested that women suffer from a taste-based discrimination (Cavalluzzo, Cavalluzzo \& Wolken, 2002, Calcagnini \& Lenti, 2008; 
Calcagnini, Iacobucci \& Ticchi 2012; Muravyev, Talavera \& Schäfer, 2009; Bellucci, Borisov \& Zazzaro, 2010; Alesina, Lotti \& Mistrulli, 2013). In particular, Beck, Behr and Madestam (2017) documented the existence of a gender bias in the credit market that lead women-led firms to pay higher interest rates and receive smaller amount of bank credit. In an international study, the presence of a gender gap in the banking system was also found by Aristei and Gallo (2016). Most of the economic literature concerning the theory of discrimination has its roots in Becker (1957). According to Becker (1957), banks can discriminate: a) by applying higher interest rates or very restrictive pre-contractual conditions; b) by demanding higher credit worthiness from women before granting them loans. Calcagnini and Lenti (2008) found that the loan denial rates are higher for female borrowers; even though they are not disadvantaged in the access to credit. In a subsequent study, Calcagnini et al. (2012) achieved two principal results: a) female firms have a higher probability of having to pledge guarantees than male firms that female firms have; $b$ ) female firms have, ceteris paribus, a lower probability of accessing bank credit despite they ask for smaller loans compared to males. Similar evidence has been found by Cavalluzzo et al. (2002) found that women suffer from a taste-based discrimination; women are more credit constrained, even though they do not pay more. Arzu and Mantovani (2016) showed that firms with higher rate of women in the board are more performing than ones with higher rate of men in the board. Nevertheless, the authors found that there are differences in the way credit is allocated relating to the gender of manager (Mascia \& Rossi, 2017). Indeed, there are more firms led by women that do not receive credit, even if they deserve it because the presence of women in corporate leadership positions may improve firm performance (Noland \& Moran, 2016; Lin, Pereira, Topalova \& Turk, 2016). The study by Muravyev et al. (2009), are largely consistent with the hypothesis of discrimination against female entrepreneurs. The authors evidenced that female-managed firms are less likely to obtain a bank loan compared to male-managed counterparts. And furthermore, when they succeed in borrowing, they are charged higher interest rates. Alesina and Giuliano (2010) found that in Italy, more than in other OECD countries, women's role is seen as that of housewives and therefore loan officers (typically males) do not see women as real entrepreneurs, but only as wife taking care the house. This is due to a social and cultural bias that is reflected in a "taste-based discrimination" in credit markets. Official lenders do not see women as appropriate and capable entrepreneurs and successful businesswomen, especially in some sectors of the economy, like that financial.

Instead, the third explanation states that differences in the level of leverage between male and female businesses is the consequence of differences relating to motivations and behavioral aspects that are typical of women (Akehurst, Simarro \& Mas-Tur,2012).This seems consistent with the view that female entrepreneurs are more risk averse than male counterparts, partly because of their lack of financial literacy that may entail a lack of confidence (Gneezy,Niederle \& Rustichini, 2003; Paserman 2010;Charness \& Gneezy,2012). Galli and Rossi (2015) argued, using data from the ECB SAFE survey that female firms apply for bank loans less often than male firms because female firms are afraid of being rejected. This is because, on the supply side, female firms, when applying for a loan, face a higher rate of rejection or receive less bank financing than do male firms. According to Tarantola and Magliocco (2007), banking is a "male-dominated" business in Italy; and this may be a further element of restraint and fear for women. Stefani and Vacca (2014) found, using the same survey, that female firms have greater difficulties in obtaining credit with respect to their male counterparts, because of both supply-side and demand-side factors. As for the demand side, female firms were less likely to apply for a bank loan because they fear a denial; in other words. They anticipate a rejection. As for the supply side, female firms receive more frequently a rejection. According to Cole and Mehran (2011), the pattern that women are inclined to have less intensive and shorter relationship with banking system make them more likely to be discouraged from applying for credit.

Evidence suggests that characteristics attributed to "successful" entrepreneurs are more commonly ascribed to men than to women (Buttner \& Rosen,1989) and that human capital plays an important role in the growth and development of a business (Treichel \& Scott,2006). This ability is often a function of the perceived human capital of the owner firm. However, since human capital is difficult to measure, owner' characteristics (such as age, education, experience) may be used as proxies (Pinazo-Dallenbach, Mas-Tur \& Lloria, 2016).

Regarding age owner, several authors found that age is a factor that effect on credit access, from both demand and supply side of loan. From the perspective of demand side, age is a factor that determines the entrepreneurs ' preference or self-selection from the credit market (Romano, Tanewski \& Smyrnios, 2001). According to Van der wijst and Thurik (1993), older entrepreneurs are less likely to apply for bank loans because they are more risky than younger owners. From the perspective of supply side, older entrepreneurs have greater likelihood to obtain credit when they apply because the banking system considers them as creditworthy (Campanella \& Serino, 2019). Younger owners are more innovative and thus more risky portfolio (Nguyen \& Luu, 2013). Briozzo and Vigier (2009, p. 37) stated that: 
"As the firm and its owner grow older, information asymmetries decrease, granting easier access to debt (a supply-side effect), while the owner's risk aversion and personal costs of bankruptcy increase with age, and thus he or she desires to use less leverage (demand side effect)".

About the impact of the educational background of the SME owner-manager and credit access (Murray, Crammond, Omeihe \& Scuotto, 2018; Scuotto et al., 2018), Coleman found that education level of manager is positively related to the firm's usage of leverage. These findings are consistent with study conducted by Bates (1990). Moreover, several authors (Slavec \& Prodan, 2012; Pandula, 2011; Zarook, Rahman \& Khanam, 2013) found out that educational level of owners have significant positive correlation with access to bank loan, highlighting that the level of education of entrepreneurs is a major determinant of likelihood to obtain bank loans. As for the demand side, Storey (2004) asserts that higher levels of education provide entrepreneurs with greater confidence in dealing with bankers and other funders when applying for loans.

Turning to experience, Cole (1998) found that experience has a positive effect on the availability of credit. Nofsinger and Wang (2011) discovered that the experience of the entrepreneur is one factor that explains the difference in external financing levels of firms. From the bank's perspective, experienced entrepreneurs are believed to be more creditworthy and are more likely to obtain bank credit when they apply for loan (Gompers, Kovner, Lerner \& Scharfstein, 2010). From demand side perspective, prior experience in industry may provide entrepreneurs with greater confidence in own skills to deal with the banking system and other funders when applying for loan (Robb \& Wolken, 2009; Welsh, Kaciak \& Minialai, 2017).

Then, in accordance with the related literature, we formalize the following hypotheses:

Hpla. Gender of the manager influences the likelihood to ask for loans;

$H p 1 b$. Gender of the manager influences the likelihood to obtain loans;

Hp2a. Education of manager influences the likelihood to ask for loans;

$H p 2 b$. Education of the manager influences the likelihood to obtain loans;

Hp3a. Age of the manager influences the likelihood to ask for loans;

$H p 3 b$. Age of the manager influences the likelihood to obtain loans;

$\mathrm{Hp} 4 \mathrm{a}$. Business experience influences the likelihood to ask for loans;

$H p 4 b$. Business experience influences the likelihood to obtain loans.

\section{Sample and Methods}

The sample consists of 428 firms. The business included in the sample is a nationally representative random sample of firms extracted from Aida. Our sample includes 178 female firms and 250 men-run firms. The research methodology adopted is quali-quantitative. Indeed, as first step, questionnaires related to the business owner' experience within the last three years were administered through a combination of computer assisted telephone interviews and the submission of written worksheets, during 2018.

The questions provide an indication as to whether female pinks are less likely to ask for loans and whether, when they apply, are less likely to obtain bank credit. Therefore, the questions indicate the factors that may predict the likelihood for business owners to apply for loans and the likelihood that loans can be approved for them. As second step, the data collected were input into Stata 15, a statistical software package in order to respond our research questions.

\subsection{Characteristics of Firms in Database}

Differences between men-owned and women-owned small businesses were explored using the T-test. Before running a T-test analysis, we developed the test to ensure respect to the assumptions of normality of the sample (Shapiro-Wilk test). The aforementioned test is statistically significant.

Table 1 presents the results and it includes the characteristics of firms that are relevant for the aim of this study. We perform a T-test of difference analysis to evaluate whether there are significant differences among women and men-led firms.

Prior research revealed that women are less educated and have less experience as business women than men. However, our analysis reveals that there no differences statistically significant between women-led firm and men-led firms in terms of education, age and business experience of the owner. A significantly lower percentage of women that had recently applied for a loan were approved (19\% vs 40\%). Instead, it seems that no differences between women and men exist in the application for loans. 
Prior research has also argued that women are less likely to use external financing than men (Cole \& Wolken 1995; Coleman \& Carsky 1996, 1999), but prefer to rely more heavily on informal and personal sources of financing such as savings, loans from family and friends.

In addition, T-test comparisons revealed that small and medium enterprises are more likely to turn to the banking system (about $54 \%$ of our sample).

These results seem to suggest that women experience higher rates of denials of credit applications. However, this analysis may suffer from the lack of interaction of other variables because the Table 1 is based on univariate analysis. In order to overcome this limit and consider also the effect of multiple factors acting in concert, we perform a multivariate analysis.

Table 1. Characteristics of firms included in the sample

\begin{tabular}{llllll}
\hline & \multicolumn{2}{l}{ Women -led firms } & \multicolumn{2}{l}{ Men-led firms } & Probability \\
\hline & Mean & Variance & Mean & Variance & P-test \\
\hline Education & 9.88 & 5.94 & 10.16 & 5,98 & 0.496 \\
\hline Age & 45,38 & 10,76 & 45,51 & 10,51 & 0.132 \\
\hline Experience & 10,59 & 5,64 & 10,27 & 5,83 & -0.583 \\
\hline & Percentage & Percentage & P (test.t) \\
\hline Recent Loan application & $56 \%$ & $52 \%$ & -0.135 \\
\hline Recent loan approved & $19 \%$ & $40 \%$ & $5.108 * * *$ \\
\hline
\end{tabular}

*significance at 0.01 level; **significance at 0.05 level; ***significance at 0.10 level

\subsection{Multivariate Analysis}

Respect to the methodology, we employ two logistic regression models. In first model, loan application (Loan_app) is used as dependent variable; in the second model loan approval (Loan_get) is used as dependent variable. The predictor variables are the same in the two regression models. In this way we can understand the firm's propensity to ask for bank loans and the ability to obtain credit, depending on the owner' personal characteristics. One question asked if the owner had applied for a bank loan within the last three years and another if he/she had obtained that loan.

As our dependent variables are binary variables that take on only the values zero and one, qualitative binary response model (QBRM) is appropriate (Horowitz and Savin, 2001). Model (LRM) are the three major QBRMs. In such situations, qualitative binary response model (QBRM) is appropriate. Ordinary least square model (OLSM), Probit regression Model (PRM) and Logistic Regression Model (LRM) are the three major QBRMs. However, several scholars (Hosmer and Lemeshow, 1989; Wasserman and Pattison, 1996) argued that Logit Regression Model is easy and flexible, giving the researcher easy access to meaningful interpretation. Therefore, in this study we decide to use the LRM to make a rigorous analysis on the statistical impact that the personal traits of the owner/manager have on firm' access to finance.

The regression model is defined as:

$$
\mathrm{y}=\alpha+\sum_{\mathrm{t}=1}^{\mathrm{n}} \beta_{\mathrm{i}} \mathrm{X}_{\mathrm{i}}+\varepsilon
$$

Where $\mathrm{Y}$ is an unobserved dependent variable; and $\mathrm{Xi}$ is vector of explanatory variables; $\beta \mathrm{i}$ is coefficient of regression for $\mathrm{Xi}$ and $\mathrm{i} \varepsilon$ is the standard error.

Hence, in order to investigate the research hypotheses, the following econometric models have been formalized:

$$
Y_{n}=\alpha+\beta_{1} \text { female }+\beta_{2} \text { ownage }+\beta_{3} \text { education }+\beta_{4} \text { experience }+\varepsilon
$$

About the dependent variables, $Y_{n}$ may assume the following modalities: 
Loan_app: This is a dummy variable coded as 1 if the owner applied for a bank loan within the last three years; 0 otherwise. This variable is a proxy of the propensity of owner to assume debt.

Loan_get: This is a dummy variable coded as 1 if the owner received the loan requested by bank. This variable is a proxy to owner's ability to obtain bank credit.

About the independent variables, they are expressive of the firm owner. In particular, they are the following:

Female: the independent variable "Female" indicates whether a firm is women-led or not. We want to verify the thesis that female firms are less likely to assume corporate debt. It is a dummy variable that sets at 1 if the firm is women-led, 0 otherwise;

Ownage: this variable indicates the years of owner. Abdulsaleh and Worthington (2013) found out that firms managed by young owner faced tighter difficulties to access debt financing because information asymmetry decreases as the age of manager increases and lead to an improved access to credit. However, older owner may be more risk averse and tend to assume low debt level than younger manager (Nakano \& Nguyen, 2011). Ownage variable expresses the age of owner measured in terms of year;

Education: this variable captures the education level of the manager. In some studies (Kasseeah \& Thoplan, 2012) educational level is measured with ordered category as primary level, secondary level, tertiary level etc. However, this study, and in accordance with Ogubazghi and Muturi (2014), it will be measured with the number of years the owner/manager attended school, as continuous value;

Experience: this variable expresses the business experience of the manager in the entrepreneurial context. According to literature (Cole, 1998) found that experience has a positive effect on the availability of credit because banks believe that experienced applicants are creditworthy (Gompers et al., 2010). It is a continuous variable and it is measured in terms of the number of years the manager spent working in the business system.

Education and experience variables may be proxies of human capital for the banking system (Zarook et al., 2013). In this sense, banks perceive owner/manager with higher educational level and major experience as creditworthy (Sena, Scott \& Roper, 2012).

Our selected independent variables are appropriate for our empirical research because they indicated the personal aspects, highlighted in the literature that may impact on the likelihood to apply for bank loans. In this way, we can investigate the thesis that women do not apply for loans, due to belief that their credit application will be denied, focusing on the perceptions of finance access (Carter \& Shaw, 2006).

\section{Results}

Before commenting on the regression analysis and answering the hypothesis of research, it is necessary to make some considerations regarding the correlation analysis between the variables distributed normally using the Pearson indices correlation matrix (Table 2).

As you can see in Table 2, many variables are significantly correlated, Pearson's indices are not high.

Table 2. Pearson correlation matrix

\begin{tabular}{lllllll}
\hline & App & GET & Female & Age & Education Experience \\
\hline App & 1 & & & & & \\
\hline GET & $0,553^{* *}$ & 1 & & & & \\
\hline Female & 0,007 & $-0,240^{* * *}$ & 1 & & & \\
\hline Age & $-0,003$ & $-0,029$ & 0,039 & 1 & & \\
\hline Education & $-0,004$ & $-0,007$ & 0,012 & $-0,043$ & 1 & 1 \\
\hline Experience & 0,039 & $-0,052$ & 0,038 & $-0,056$ & $-0,016$ & 1
\end{tabular}

*** Correlation is significant at the 0.01 level; **Correlation is significant at the 0.05 level; *Correlation is significant at the 0.10 level 
The statistical results obtained from two regression models are reported in the Table 3.

As with the first regression model, the variable Female is not correlated with the dependent variable. This means that women are not less likely to apply for a loan than men. The only variable that appears to determine the loan application is Age (+). These results indicate that an older applicant is more likely to apply for bank loans.

As with the second regression model, the variable Female is statistically and negatively correlated with the dependent variable demonstrating that women, controlling for other variables, are more likely to be denied for a loan. As in the first model, the only variable that is correlated to the loan approval is Age (+).

These results seem to suggest that access to debt capital is function of gender and age owner.

Table 3. Logistic regression results (odds ratio and z)

\begin{tabular}{lll}
\hline & Loan_app & Loan_get \\
\hline (Constant) & $0.121(-3.90)^{* * *}$ & $0.087(-4.15)^{* * *}$ \\
\hline Female & $1.047(0.33)$ & $0.0311(-4.95)^{* * *}$ \\
\hline Age & $1.051(5.04)^{* * *}$ & $1.042(3.92)^{* * *}$ \\
\hline Education & $0.985(-0.81)$ & $1.019(1.01)$ \\
\hline Experience & $1.017(0.97)$ & $0.998(-0.08)$ \\
\hline LR chi $^{2}$ & $28.75^{* * *}$ & $42.18^{* * *}$ \\
\hline Pseudo $^{2}$ & 0.0487 & 0.0793
\end{tabular}

***Correlation is significant at the 0.01 level; **Correlation is significant at the 0.05 level; * Correlation is significant at the 0.10 level

Therefore, in the Table 4 and 4.1 we show the result of the Hosmer-Lemeshow Test. In this test, if the p-value is greater than 0.05 , it means that we have a good predicting model. As you can see, in the two regression, the test reported a p-value greater of 0.05 (respectively it is equal to 0.921 and 0.079 ). Thus, our test performed in a good way.

Table 4. Test di Hosmer \& Lemeshow (Loan_app as dependent variable)

\begin{tabular}{lll}
\hline Chi-quadrato & df & Sign. \\
\hline 3,204 & 8 & 0,921 \\
\hline
\end{tabular}

Table 4.1. Test di Hosmer \& Lemeshow (Get_app as dependent variable)

\begin{tabular}{lcc}
\hline Chi-quadrato & df & Sign. \\
\hline 14.11 & 8 & 0,079 \\
\hline
\end{tabular}




\section{Conclusion and Implications}

This article is focused upon whether women-led firms are more credit-constrained than men counterparts or whether they are afraid to apply for bank loans.

Our empirical results show that there are no differences between loan application requested by women or men. This means that women are not afraid to apply for a loan. Our result contradicts the the thesis that women are self-restrained from applying for bank loans because of fear of rejection (Hpla is not confirmed). However, women are less likely to be approved their loans than male counterparts. Thus, women do not appear to be averse to taking on corporate debt, as some prior research has suggested. However, contradicting some prior research, we found that women ask for bank loans, but they experience higher levels of denial than men. This result is consistent with the thesis that the supply discrimination, pioneered by Beck (1971), towards women-led firm exist in the credit market (Hplb is confirmed). According to this view, women are either not discouraged in the credit application process with the end result that they are less likely to obtain bank credit. This phenomenon of invisible barriers in the credit markets of female managers, is commonly termed as "glass ceiling" (Ansari, 2016), with effects also in their career progression as entrepreneurs (Holton, \& Dent, 2016).

Regard the owner' personal characteristics, we found that only owner' age appear a significant predictor both of probability to ask for a loan and both of the likelihood get rejected when applying for a loan. Our empirical findings stated that older applicant is more likely to apply for bank loan than younger entrepreneurs (Hp2a is confirmed). This result may be due to the fact that a younger owner prefers to exhaust internally generated sources of funds, such as retained earnings, before they turn to banking system. Consistent with the literature, younger borrowers may refrain from applying for a loan because they consider the costs of application. Younger applicants can be classified as "discouraged borrowers" as they are less likely to ask for loans to save the costs of application because of possible rejection. From the perspective of demand side, age is a factor that determines the owner/manager's self-selection from bank credit.

From the perspective of supply side, older applicant is more likely to get their loan application approved because they are less opaque (Hp2b is confirmed). This assumption is coherent with the prevailing view that older firms are less opaque (Krishnaswami et al., 1999) because they have a longer company history, are more established and and can prove their capacity to refund bank loans. Information asymmetry play an important role in the lending decision-making process and it decreases as the age of entrepreneurs increases and lead to an improved access to credit (Abdulsaleh and Worthington, 2013). This result means that age of the borrower impacts on the probability to be funded because he /she appears less risky than younger one. In general, lenders prefer borrowers who have a track record of financial indexes, can show borrower' financial soundness (Cole and Wolken 1995).

Conversely, our study found no evidence that other personal owner characteristics (education and experience) does not impact either on the probability to ask for loans and or on the likelihood to be refund (Hp3a, Hp3b; Hp4a; Hp4b are not supported).In addition, our study shows that there are no statistical differences in terms of owner's age, education and business experience between women and me. This result strengthens the argument that a gender-discrimination towards women enterprises in credit market is there. We analyze only Italian market because Italy supported the presence of women on board, through specific legislative provisions (the quota law). Indeed, before the quota law, the presence of women on boards was less than $10 \%$. Actually, as result of this legislative effort, Italy is now collocated in fourth place in Europe for the number of women on corporate boards, with an average of about $30 \%$ (Rossi, Galasso \& Capasso, 2017).

However, our study is not free from limitations that suggest avenues for future research.

First, our results are contextual and in future we may generalize empirical findings by using a larger European sample. Second, this study does not examine the effect of gender on the interest rates charged by banks when firms succeed in borrowing. In other words, future research may benefit from understanding if, when application is accepted, the pricing of credit is influenced by owner' gender. To further analyze the correlation between genders' owner and pricing of credit charged by banks, the study could be extended using different samples divided in countries with different cultural backgrounds. Prospectively, these important issues remain for future research.

\section{References}

Abdulsaleh, A. M., \& Worthington, A. C. (2013). Small and medium-sized enterprises financing: A review of literature. International Journal of Business and Management, 8(14), 36. https://doi.org/10.5539/ijbm.v8n14p36

Akehurst, G., Simarro, E., \& Mas-Tur, A. (2012). Women entrepreneurship in small service firms: Motivations, barriers and performance. The Service Industries Journal, 32(15), 2489-2505. 
Alesina, A., \& Giuliano, P. (2010). The power of the family. Journal of Economic Growth, 15(2), 93-125.

Alesina, A., Lotti, F., \& Mistrulli, P. (2013). Do women pay more for credit? Evidence from Italy. Journal of the European Economic Association, 11, 45-66. https://doi.org/10.1111/j.1542-4774.2012.01100.x

Alessandrini, P., Presbitero, A. F., \& Zazzaro, A. (2009). Bank size or distance: what hampers innovation adoption by SMEs?. Journal of Economic Geography, 10(6), 845-881. https://doi.org/10.1093/jeg/lbp055

Angori, G., Aristei, D., \& Gallo, M. (2017, May 24). Lending technologies, banking relationships, and firms' access to credit in Italy: the role of firm size. Banking Relationships, and Firms' Access to Credit in Italy: The Role of Firm Size.

Ansari, N. (2016). Respectable femininity: a significant panel of glass ceiling for career women. Gender in Management: An International Journal, 31(8), 528-541. https://doi.org/10.1108/GM-03-2015-0012

Aristei, D., \& Gallo, M. (2016). Does gender matter for firms' access to credit? Evidence from international data. Finance Research Letters, 18, 67-75. https://doi.org/10.1016/j.frl.2016.04.002

Arzu, D., \& Mantovani, G. M. (2016). The Gender Contribution to the Corporate Governance and the Corporate Performance.

Asiedu, E., Freeman, J. A., \& Nti-Addae, A. (2012). Access to credit by small businesses: How relevant are race, ethnicity, and gender?. The American Economic Review, 102(3), 532-537. https://doi.org/10.1257/aer.102.3.532

Azam, J. P., Biais, B., Dia, M., \& Maurel, C. (2001). Informal and formal credit markets and credit rationing in Cote d'Ivoire. Oxford Review of Economic Policy, 17(4), 520-534. https://doi.org/10.1093/oxrep/17.4.520

Baliamoune-Lutz, M., \& Lutz, S. (2017). Gender and firm performance in middle-eastern and African economies.

Beck, T., Behr, P., \& Madestam, A. (2018). Sex and credit: Do gender interactions matter for credit market outcomes?. Journal of Banking \& Finance, 87, 380-396. https://doi.org/10.1016/j.jbankfin.2017.10.018

Beck, T., Demirgüç-Kunt, A., \& Levine, R. (2005). SMEs, Growth, and Poverty: Cross-country Evidence. World Bank mimeo. https://doi.org/10.1007/s10887-005-3533-5

Becker, G. (1957). The Economics of Discrimination. Chicago, IL: University of Chicago Press.

Bell, C., Srintvasan, T. N., \& Udry, C. (1997). Rationing, spillover, and interlinking in credit markets: the case of rural Punjab. Oxford Economic Papers, 49(4), 557-585. https://doi.org/10.1093/oxfordjournals.oep.a028625

Bellucci, A., Borisov, A., \& Zazzaro, A. (2010). Does gender matter in bank-firm relationships? Evidence from small business lending. Journal of Banking \& Finance, 34(12), 2968-2984.

Berger, A. N., \& Udell, G. F. (1995). Relationship lending and lines of credit in small firm finance. Journal of Business, 351-381. https://doi.org/10.1086/296668

Berger, A. N., \& Udell, G. F. (2002). Small business credit availability and relationship lending: The importance of bank organisational structure. The Economic Journal, 112(477), F32-F53.

Berger, A. N., \& Udell, G. F. (2006). A more complete conceptual framework for SME finance. Journal of Banking \& Finance, 30(11), 2945-2966. https://doi.org/10.1016/j.jbankfin.2006.05.008

Blanchflower, D. G., Levine, P. B., \& Zimmerman, D. J. (2003). Discrimination in the small-business credit market. The Review of Economics and Statistics, 85(4), 930-943. https://doi.org/10.1162/003465303772815835

Briozzo, A., \& Vigier, H. (2009). A demand-side approach to SMES'capital structure: evidence from Argentina. Journal of Business and Entrepreneurship, 21(1), 30.

Buttner, E. H., \& Rosen, B. (1989). Funding New Business Ventures: Are Decision Makers Biased Against Women Entrepreneurs?. Journal of Business Venturing, 4, 249-261. https://doi.org/10.1016/0883-9026(89)90015-3

Calcagnini, G., \& Favaretto, I. (2009). L'economia della piccola impresa. FrancoAngeli, Milano.

Calcagnini, G., \& Lenti, E. (2008). L'accesso al credito per l'imprenditoria femminile. I vincoli finanziari alla crescita delle imprese, Carocci, Roma.

Calcagnini, G., Iacobucci, D., \& Ticchi, D. (2012). Razionamento del credito e dimensioni di impresa. Moneta e credito, 51(202).

Campanella, F., \& Serino, L. (2019). Do personal characteristics of manager affect Smes’ Access to Bank Loan?. International Journal of Economics, Business and Finance, 6(2), 1-14. 
Carter, S. (2000). Gender and enterprise. Enterprise and Small Business. Principles, Practice and Policy, pp. 166-181. Harlow: Prentice Hall/Pearson Education Limited.

Carter, S. L., \& Shaw, E. (2006). Women's business ownership: Recent research and policy developments.

Cassar, G. (2004). The financing of business start-ups. Journal of Business Venturing, 19(2), 261-283.

Cavalluzzo, K. S., \& Cavalluzzo, L. C. (1998). Market structure and discrimination: The case of small businesses. Journal of Money, Credit and Banking, 771-792. https://doi.org/10.2307/2601128

Cavalluzzo, K. S., Cavalluzzo, L. C., \& Wolken, J. D. (2002). Competition, small business financing, and discrimination: Evidence from a new survey. The Journal of Business, 75(4), 641-679.

Cesaroni, F. (2010). Donne imprenditrici e banche. Le ragioni di un rapporto difficile.

Charness, G., \& Gneezy, U. (2012). Strong evidence for gender differences in risk taking. Journal of Economic Behavior \& Organization, 83(1), 50-58. https://doi.org/10.1016/j.jebo.2011.06.007

Christiansen, L., Lin, H., Pereira, J., Topalova, P. B., \& Turk, R. (2016). Gender diversity in senior positions and firm performance: Evidence from Europe.

Cole, R. A. (1998). The importance of relationships to the availability of credit. Journal of Banking \& Finance, 22(6-8), 959-977.

Cole, R. A., \& Mehran, H. (2011). Gender and the availability of credit to privately held firms: evidence from the surveys of small business finances.

Cole, R. A., \& Wolken, J. D. (1995). Financial services used by small businesses: Evidence from the 1993 National Survey of Small Business Finances. Fed. Res. Bull., 81, 629.

Coleman, S. (2000). Access to capital and terms of credit: A comparison of men- and women-owned small businesses. Journal of Small Business Management, 38(3), 37-52.

Coleman, S. (2004). Access to debt capital for women-and minority-owned small firms: does educational attainment have an impact?. Journal of Developmental Entrepreneurship, 9(2), 127.

Coleman, S., \& Carsky, M. (1996). Women owned businesses and bank switching: The role of customer service. The Journal of Entrepreneurial Finance, 5(1), 75.

Coleman, S., \& Carsky, M. (1999). Sources of capital for small family owned businesses: Evidence from the national survey of small business finances. Family Business Review, 12(1), 73-85.

Coleman, S., \& Robb, A. (2009). A comparison of new firm financing by gender: evidence from the Kauffman Firm Survey data. Small Business Economics, 33(4), 397. https://doi.org/10.1007/s11187-009-9205-7

Croson, R., \& Gneezy, U. (2004). Gender differences in preferences. Mimeo, Graduate School of Business, University of Chicago

Degryse, H., \& Van Cayseele, P. (2000). Relationship lending within a bank-based system: Evidence from European small business data. Journal of Financial Intermediation, 9(1), 90-109. https://doi.org/10.1006/jfin.1999.0278

European Commission (2003). Smes in Europe 2003 (Enterprise Publications, Luxembourg).

Fabowale, L., Orser, B., \& Riding, A. (1995). Gender, structural factors, and credit terms between Canadian small businesses and financial institutions. Entrepreneurship: Theory and Practice, 19(4), 41-66.

Fatoki, O., \& Odeyemi, A. (2010). Which new small and medium enterprises in South Africa have access to bank credit?. International Journal of Business and Management, 5(10), 128. https://doi.org/10.5539/ijbm.v5n10p128

Fay, M., \& Williams, L. (1993). Gender bias and the availability of business loans. Journal of Business Venturing, 8(4), 363-376. https://doi.org/10.1016/0883-9026(93)90005-P

Galli, E., \& Rossi, P. S. S. (2017). Bank Credit Access and Gender Discrimination: An Empirical Analysis. Working Paper.

Ghosh, P., Mookherjee, D., \& Ray, D. (2000). Credit rationing in developing countries: an overview of the theory. Readings in the Theory of Economic Development, 383-401.

Gneezy, U., Niederle, M., \& Rustichini, A. (2003). Performance in competitive environments: Gender differences. The Quarterly Journal of Economics, 118(3), 1049-1074. https://doi.org/10.1162/00335530360698496 
Gompers, P., Kovner, A., Lerner, J., \& Scharfstein, D. (2010). Performance persistence in entrepreneurship. Journal of Financial Economics, 96(1), 18-32. https://doi.org/10.1016/j.jfineco.2009.11.001

Hanedar, E. Y., Broccardo, E., \& Bazzana, F. (2014). Collateral requirements of SMEs: The evidence from less-developed countries. Journal of Banking \& Finance, 38, 106-121.

Holton, V., \& Dent, F. E. (2016). A better career environment for women: developing a blueprint for individuals and organisations. Gender in Management: An International Journal, 31(8), 542-561.

Irwin, D., \& Scott, J. M. (2010). Barriers faced by SMEs in raising bank finance. International Journal of Entrepreneurial Behavior \& Research, 16(3), 245-259. https://doi.org/10.1108/13552551011042816

Kasseeah, H., \& Thoplan, R. (2012). Access to financing in a small island economy: Evidence from Mauritius. Journal of African Business, 13(3), 221-231. https://doi.org/10.1080/15228916.2012.727753

Kira, A. R. (2013). The Evaluation of the Factors Influence the Access to Debt Financing by Tanzanian SMEs. European Journal of Business and Management, 5, 1-24.

Marlow, S., \& Patton, D. (2005). All credit to men? Entrepreneurship, finance, and gender. Entrepreneurship Theory and Practice, 29(6), 717-735. https://doi.org/10.1111/j.1540-6520.2005.00105.x

Mascia, D. V. (2018). Young Enterprises and Bank Credit Denials (No. 844). ADBI Working Paper Series.

Mascia, D. V., \& Rossi, S. P. (2017). Is there a gender effect on the cost of bank financing?. Journal of Financial Stability, 31, 136-153. https://doi.org/10.1016/j.jfs.2017.07.002

Moro, A., Wisniewski, T., \& Mantovani, G. (2017). Does a Manager's Gender Matter When Accessing Credit? Evidence from European Data.

Mukiri, W. G. (2008). Determinants of access to bank credit by micro and small enterprises in Kenya, UNPD: Growing Inclusive Markets.

Muravyev, A., Talavera, O., \& Schäfer, D. (2009). Entrepreneurs' gender and financial constraints: Evidence from international data. Journal of Comparative Economics, 37(2), 270-286. https://doi.org/10.1016/j.jce.2008.12.001

Murray, A., Crammond, R. J., Omeihe, K. O., \& Scuotto, V. (2018). Establishing successful methods of entrepreneurship education in nurturing new entrepreneurs. Journal of Higher Education Service Science and Management, 1(1).

Nakano, M., \& Nguyen, P. (2011). Do older boards affect firm performance? An empirical analysis based on Japanese firms.

Nguyen, N., \& Luu, N. (2013). Determinants of financing pattern and access to formal-informal credit: The case of small and medium sized enterprises in Viet Nam.

Niederle, M., \& Vesterlund, L. (2011). Gender and competition. Annu. Rev. Econ., 3(1), 601-630.

Nofsinger, J. R., \& Wang, W. (2011). Determinants of start-up firm external financing worldwide. Journal of Banking \& Finance, 35(9), 2282-2294. https://doi.org/10.1016/j.jbankfin.2011.01.024

Noland, M., Moran, T., \& Kotschwar, B. R. (2016). Is gender diversity profitable? Evidence from a global survey.

Nussbaum, M. C. (2011). Creating capabilities. Harvard University Press.

Ogubazghi, S. K., \& Muturi, W. (2014). The effect of age and educational level of owner/managers on SMMEs' access to bank loan in Eritrea: evidence from Asmara City. American Journal of Industrial and Business Management, 4(11), 632. https://doi.org/10.4236/ajibm.2014.411069

Ongena, S., Popov, A., \& Udell, G. (2013). 'When the cat's away the mice will play:' Does regulation at home affect bank risk taking abroad?. Journal of Financial Economics, 108, 727-750.

Ono, A., \& Uesugi, I. (2009). Role of collateral and personal guarantees in relationship lending: Evidence from Japan's SME loan market. Journal of Money, Credit and Banking, 41(5), 935-960.

Pandula, G. (2011, February). An empirical investigation of small and medium enterprises' access to bank finance: The case of an emerging economy. Proceedings of ASBBS Annual Conference (Vol. 18, No. 1, p. 18).

Paserman, M. (2010). Gender Differences in performance in Competitive Environments? Evidence from Professional Tennis Players. CEPR Discussion Paper No. DP6335. 
Petersen, M., \& Rajan, R. (1994). The Benefits of Lending Relationships: Evidence from Small Business Data. Journal of Finance, 49, 3-37. https://doi.org/10.1111/j.1540-6261.1994.tb04418.x

Pinazo-Dallenbach, P., Mas-Tur, A., \& Lloria, B. (2016). Using high-potential firms as the key to achieving territorial development. Journal of Business Research, 69(4), 1412-1417. https://doi.org/10.1016/j.jbusres.2015.10.117

Powell, M., \& Ansic, D. (1997). Gender differences in risk behaviour in financial decision-making: An experimental analysis. Journal of Economic Psychology, 18(6), 605-628. https://doi.org/10.1016/S0167-4870(97)00026-3

Reding, V. (2013). And Yet it is Coming: A Gender Quota in Business Leadership.

Riding, A. L., \& Swift, C. S. (1990). Women business owners and terms of credit: Some empirical findings of the Canadian experience. Journal of Business Venturing, 5(5), 327-340.

Robb, A., \& Walken, J. (2002, March). Firm, Owner, and Financing Characteristics: Differences between Female- and Male-owned Small Businesses. Federal Reserve Working Paper, Series 2002-18.

Romano, C. A., Tanewski, G. A., \& Smyrnios, K. X. (2001). Capital structure decision making: A model for family business. Journal of Business Venturing, 16(3), 285-310. https://doi.org/10.1016/S0883-9026(99)00053-1

Rossi, M., Galasso, S., \& Capasso, A. (2017). Women Do it Better: An Investigation on the Association between Gender Diversity In Board of Directors and the Financial Performance. International Journal of Economics and Financial Issues, 7(6), 41-50.

Scuotto, V., \& Murray, A. (2018). Effectiveness of Internal Entrepreneurship Education Ecosystem on forming a new entrepreneurial mind-set. Experiential Learning for Entrepreneurship, Chapter 3, pp.125-144.

Scuotto, V., Serravalle, F., Murray, A., \& Viassone, M. (2019). The Shift Towards a Digital Business Model: A Strategic Decision for the Female Entrepreneur. Women Entrepreneurs and Strategic Decision Making in the Global Economy, pp. 120-143. IGI Global. https://doi.org/10.4018/978-1-5225-7479-8.ch007

Sena, V., Scott, J., \& Roper, S. (2012). Gender, borrowing patterns and self-employment: some evidence for England. Small Business Economics, 38, 467-480. https://doi.org/10.1007/s11187-010-9272-9

Slavec, A., \& Prodan, I. (2012). The influence of entrepreneur's characteristics on small manufacturing firm debt financing. JEEMS Journal of East European Management Studies, 17(1), 104-130.

Stefani, M. L., \& Vacca, V. (2012). The Access to Credit by Female Enterprises: Evidence from a Survey on European SMEs.

Storey, D. J. (2004). Racial and gender discrimination in the micro firms credit market? Evidence from Trinidad and Tobago. Small Business Economics, 23(5), 401-422. https://doi.org/10.1007/s11187-004-7259-0

Strier, R. (2010). Women, poverty, and the microenterprise: Context and discourse. Gender, Work \& Organization, 17(2), 195-218. https://doi.org/10.1111/j.1468-0432.2009.00486.x

Tarantola Ronchi, A. M., \& Magliocco, A. (2007). La presenza delle donne italiane nei senior managem.

Tardivo, G., Miglietta, N., Schiesari, R., \& Battisti, E. (2012). Il sistema finanziario locale come fattore di competitività e sviluppo delle imprese. L'esperienza della Banca d'Alba. Sinergie Referred Electronic Conference Proceeding, 177-192.

Treichel, M. Z., \& Scott, J. A. (2006). Women-owned businesses and access to bank credit: Evidence from three surveys since 1987. Venture Capital, 8(1), 51-67. https://doi.org/10.1080/13691060500453726

Van der Wijst, N., \& Thurik, R. (1993). Determinants of small firm debt ratios: An analysis of retail panel data. Small Business Economics, 5(1), 55-65. https://doi.org/10.1007/BF01539318

Vera, D., \& Onji, K. (2010). Changes in the banking system and small business lending. Small Business Economics, 34(3), 293-308. https://doi.org/10.1007/s11187-008-9119-9

Welsh, D. H., Kaciak, E., \& Minialai, C. (2017). The influence of perceived management skills and perceived gender discrimination in launch decisions by women entrepreneurs. International Entrepreneurship and Management Journal, 13(1), 1-33. https://doi.org/10.1007/s11365-015-0379-y

Zarook, T., Rahman, M. M., \& Khanam, R. (2013). Management skills and accessing to finance: evidence from Libya's SMEs. International Journal of Business and Social Science, 4(7), 106-115.

Zindiye, S. (2008). An empirical investigation into the factors affecting the performance of small and medium enterprises in the manufacturing sector of Harare, Zimbabwe. Doctoral dissertation, University of Fort Hare. 